\title{
The Crown's Duty to Consult Aboriginal People
}

\author{
THOMAS ISAAC AND ANTHONY KNOX*
}

The Crown's duty to consult Aboriginal people when contemplating an infringement of an Aboriginal or treaty right is becoming settled in law. The procedural and substantive content of that duty, however, remains uncertain. These authors demonstrate the need for certainty for industries contemplating the exploitation of lands potentially subject to Aboriginal and treaty rights, and discuss where we can look for certainty.
Le devoir de la Couronne de consulter les Autochtones au moment d'envisager une infraction à un droit ou traité autochtone est un principe juridique établi. Le fond et la procédure en demeurent cependant incertains. Les auteurs démontrent que certains secteurs d'activité doivent envisager l'exploitation de terres pouvant éventuellement faire l'objet d'un traité ou de droits autochtones et examinent où il faut s'adresser à cet égard.

\section{TABLE OF CONTENTS}

I. INTRODUCTION . . . . . . . . . . . . . . . . . . . . . 49

II. Consultation: An Historical Perspective $\ldots \ldots \ldots \ldots \ldots \ldots \ldots . \ldots 1$

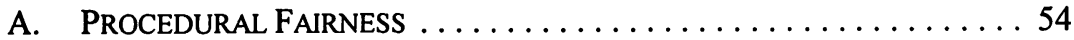

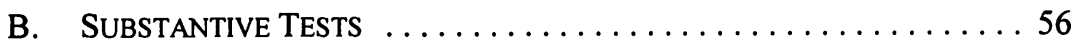

III. Consultation AND Aboriginal PEOPLE $\ldots \ldots \ldots \ldots \ldots \ldots \ldots \ldots 57$

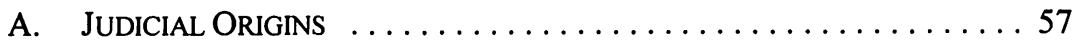

B. SOURCE OF THE DUTY TO CONSULT $\ldots \ldots \ldots \ldots \ldots \ldots \ldots \ldots \ldots$

C. TRIGGERING THE DUTY TO CONSULT $\ldots \ldots \ldots \ldots \ldots \ldots \ldots \ldots . \ldots \ldots$

D. NATURE OF THE DUTY TO CONSUlt $\ldots \ldots \ldots \ldots \ldots \ldots \ldots \ldots$

E. Duty of ABoriginal PEOPLE Not TO

FRUSTRATE THE CONSULTATION ....................6 64

F. Case Law: Procedural ERrors $\ldots \ldots \ldots \ldots \ldots \ldots \ldots \ldots 6$

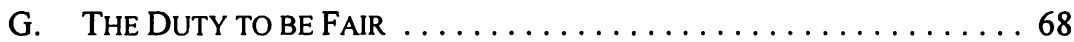

H. MINISTERIAL DISCRETIONARY AUTHORITY $\ldots \ldots \ldots \ldots \ldots \ldots 70$

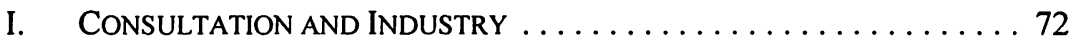

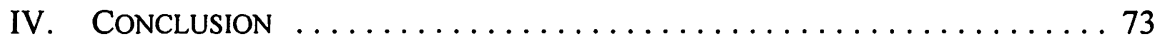

\section{INTRODUCTION}

Careful study of the law relating to the Crown's duty to consult Aboriginal people leads to the conclusion that the most important unresolved issue is how to involve the federal, provincial and territorial governments of Canada in appropriate consultation so as to ensure that there is an acceptable level of business certainty in industry's interests in natural resources which are, or may be, subject to Aboriginal and treaty rights. Although certain questions remain, the law is becoming clear as to the Crown's duty to consult Aboriginal people to allow for reasonable legal predictions of the validity of most consultation activity. On lands both subject and not subject to treaty, an acceptable level of business certainty should now be obtainable by resource developers in respect to natural resources actually or potentially subject to Aboriginal and treaty rights if, among other things, the appropriate face 
of the Crown effects appropriate consultation at the appropriate time with the appropriate Aboriginal people.

The Crown's duty to consult Aboriginal people was first enunciated by the Supreme Court of Canada in R. v. Sparrow' in 1990, though its roots in law and equity are much older. Since its first appearance, the Crown's duty to consult has inspired considerable confusion and conflicting views in the academic literature as to its meaning and implications. ${ }^{2}$ Thirteen years of case law, taken together with related legal concepts, has clarified what consultation with Aboriginal people will be accepted by the courts as appropriate in the circumstances.

The one important non-legal difficulty which continues to exist regarding the Crown's duty to consult and accommodate Aboriginal people is that the Crown, in all Canadian jurisdictions, is regularly found by the courts to have failed to carry out its duty to consult properly. This probably reflects an inappropriate institutional response by the Crown to the challenge imposed by the developing law relating to Aboriginal and treaty rights.

There are two continuing areas of legal vagueness resulting from conflicting judicial decisions. The first is whether Crown consultation need occur in circumstances in which no Aboriginal right has been proven or no treaty right exists. ${ }^{3}$ The second is the question of whether the provincial Crown has any authority to consult Aboriginal people in connection with their infringements of Aboriginal and treaty rights. ${ }^{4}$ The appeals from the decisions of the British Columbia Court of Appeal will, in due course, finally resolve these questions.

The case law relating to a substantive discussion and understanding of the Crown's duty to consult is restricted to a limited number of judicial decisions. The historical roots of the

1 S.C.R. 1075 [Sparrow].

S. Lawrence \& P. Macklem, "From Consultation to Reconciliation: Aboriginal Rights and the Crown's Duty to Consult" (2000) 79 Can. Bar Rev. 252; J. Woodward, "First Nations' Empowerment Over Traditional Territories: An End to False Consultation" (Pacific Business \& Law Institute, Vancouver, 18-19 November 1999) [unpublished]; R.J.M. Janes \& J.J. Woodward, "Fulfilling the Promise of Consultation: Strategies and Tactics" (Ontario Institute of Continuing Legal Education, Toronto, Ontario, 29 January 1999) [unpublished]; and T. Gouge, "Aboriginal Consultation in The Regulation of Resource Development Projects: An Industry Perspective" (Pacific Business \& Law Institute, Vancouver, 1 May 2002) [unpublished].

3 Taku River Tlingit First Nation v. Ringstad, [2002]4 W.W.R. 19 (B.C.C.A.) [Taku River] and Haida Nation v. British Columbia (Minister of Forests), [2002] 6 W.W.R. 243 (B.C.C.A.) [Haida].

4 In Paul v. British Columbia (Forest Appeals Commission) (2001), 201 D.L.R. (4th) 251 (B.C.C.A.) [Paul], the British Columiba Court of Appeal, citing Delgamuukw v. British Columbia, [1997] 3 S.C.R. 1010 [Delgamuukw], held that a provincially constituted quasi-judicial tribunal, such as the British Columbia Forest Appeals Commission, does not possess the constitutional authority to consider Aboriginal title and Aboriginal and treaty rights issues since they form a core area of federal jurisdiction under s. 91(24) of the Constitution Act, 1867 (U.K.), 30 \& 31 Vict., c. 3 (reprinted in R.S.C. 1985, App. II, No. 5). This decision places a major obstacle in the way of the government of British Columbia being able to consider seriously, by way of consultation and otherwise, the rights of Aboriginal people when raised within the context of a decision by a provincial authority. From this perspective, this decision clearly runs counter to the Supreme Court of Canada decisions that state that the provincial Crown has a duty to consult, and by implication, must be able to use the fruits of that consultation in making decisions, including accommodation where appropriate, that may impact upon the rights of Aboriginal people. For commentary, see T. Isaac, "Provincial Jurisdiction, Adjudicative Authority and Aboriginal Rights: A Comment on Paul v. B.C. (Forest Appeals Commission)" (2002) 60:1 Advocate (B.C.) 77. The Supreme Court of Canada allowed the appeal in Paul in June 2003. 
concept of consultation and analogies in broader Canadian law will be examined in order to: (i) develop a better understanding of the Crown's duty to consult; and (ii) provide suggestions for guiding its future development.

The legal nature of the duty to consult is procedurally related to the common law duty of procedural fairness in general administrative law, and substantively related to the various doctrines dealing with the proper exercise of administrative authority in general administrative law. An understanding of the underlying principles of fairness in both administrative law and equity is key to implementing a proper consultation regime with respect to the justification of infringements to existing Aboriginal and treaty rights. These doctrines provide an enormous body of jurisprudence from Anglo-Canadian courts to guide all stakeholders in conducting consultation in a manner to which the courts will predictably defer.

\section{Consultation: An Historical Perspective}

There is an unfortunate tendency among some practitioners and commentators to treat the Aboriginal law doctrines enunciated by the Canadian judiciary over the last few decades as the sui generis subjects of a legal science divorced from the rest of the common law and equity. Study of Aboriginal case law, together with the common law and equity, make it clear that such an approach is fundamentally misleading. To understand better the Crown's duty to consult and accommodate Aboriginal people, it is worth looking at legal uses of consultation in the non-Aboriginal context, along with some of the Aboriginal law decisions that deal with the Crown's duty to consult and accommodate Aboriginal people.

In essence, the duty to consult Aboriginal people is the Crown seeking a fair decision through fair procedures in accommodating governmentally sanctioned action affecting Aboriginal people. This duty to consult and accommodate Aboriginal people has some of its intellectual roots in equity. Equity began more than eight hundred years ago as a mechanism by which the King's chief servant, the Lord Chancellor, would determine what was fair and reasonable when the common law provided no remedy. ${ }^{5}$ His Court of Chancery used a simple procedure of bills of complaint, answers, interrogatories, and commissions of inquiry to determine a fair and equitable accommodation to the circumstances set out in the bill of complaint. ${ }^{6}$ Chancery procedure was also used in the Star Chamber ${ }^{7}$ to work out the proper measures for reigning in powerful subjects, and in the Court of Requests ${ }^{8}$ to work out how best to deal with the complaints of poor persons. These early institutional reactions utilized what amounted to a process of informed consultation to seek a fair result backed by official sanction.

$5 \quad$ Sir F. Pollock \& F.W. Maitland, The History of English Law, vol. 1, 2d ed. (Cambridge: Cambridge University Press, 1968) at 189-90; H.G. Hanbury \& R.H. Maudlsey, Modern Equity, 13th ed. (London: Stevens \& Sons, 1989) at 6.

- W.J. Jones, The Elizabethan Court of Chancery (Oxford: Clarendon Press, 1967).

I.S. Leadam \& J.F. Baldwin, Select Cases Before The King's Counsel in Star Chambers 1477-1544, vol. 25 (London: Selden Society XVI, 1903) at 1911.

$8 \quad$ I.S. Leadam, Select Papers of The Court of Requests (London: Selden Society XII, 1898). 
The distilled result of Chancery procedure in equity is that where a person deals with the property of another, that person becomes, in conscience, subject to duties to the owner of the property. Such duties are referred to as "fiduciary" and arise under a constructive trust because they are bona fide, reflecting the good faith of which the Lord Chancellor was the judge, and a relationship not subject to an express and clearly defined trust. ${ }^{9}$

With procedures using essentially similar principles as the Chancery procedure of old, the National Native Title Tribunal and the Native Title Register of Australia deal on a case-bycase basis with the issues of resource access resulting from Australian judicial acceptance of the existence of Aboriginal rights similar to those now recognized in Canada. ${ }^{10}$

Australia's Aboriginal people have no constitutional protection of their Aboriginal rights. Those rights exist in common law and have been regulated by statute. In contrast, Canada's Aboriginal people enjoy protection under s. 35(1) of the Constitution Act, 1982." The evidence from Australia seems to suggest that little certainty is being obtained by resource developers beyond that of individual agreements between resource developers and Aboriginal people. Canada's constitutional approach to Aboriginal rights and the justification of their infringement through appropriate Crown consultation may result in as much, if not more, commercial certainty and finality if its jurisprudential development continues to follow the course described in this article.

The origin of the Crown's sui generis fiduciary duty to Aboriginal people is found in constructive trust theory. ${ }^{12}$ The fiduciary duty would appear to have the indicia of any other fiduciary duty in circumstances in which the Aboriginal beneficiaries are the undisputed beneficial owners of the property in question, for example, the lands comprising an Indian reserve. However, when the property in question is subject to other interests, for example, lands subject to hunting and fishing rights set out in a treaty, the indicia of the Crown's fiduciary duty would appear to be unique. ${ }^{13}$ The Crown has broad public duties which conflict with those owed to the beneficiary of the constructive trust. The basic principles of a constructive trust create an obligation on the trustee not to act knowingly contrary to the

' Hanbury \& Maudsley, supra note 5 at 280. Such circumstances can create a resulting trust. In $R . v$. Guerin, [1984] 2 S.C.R. 335 at 386-87, Dickson J., while denying a constructive trustee role for the Crown, first enunciated the sui generis trust-like relationship between Crown and Aboriginal people in such circumstances.

11 A. Knox, "Aboriginal Title and Mineral Development in Canada and Australia," Proceedings of the Rocky Mountain Mineral Law Forty-Sixth Annual Institute, Denver, Rocky Mountain Mineral Law Foundation (2000); see also M.A. Hunt, "Native Title and Aboriginal Heritage Issues Affecting Oil and Gas Exploration and Production in Australia" (2001) 19:4 J. of Energy and Natural Resources L. 364.

1 Being Schedule B to the Canada Act 1982 (U.K.), 1982, c. 11, as am. by the Constitution Amendment Proclamation, 1983, R.S.C. 1985, App. II, No. 46 [Constitution Act, 1982].

Supra note 7.

1.3 Ibid. See also Gouge, supra note 2 at 5.4-5.7. The insight that the fiduciary duty of the Crown to Aboriginal people is not monolithic is valuable. By being sui generis or unique, the duty is its own unclosed category of relationships that will multiply with the circumstances to which the fundamental notion of the Crown's trust-like relationship is applied. It is all quite reminiscent of the Chancellor's conscience, and possibly the closest approximation that the courts can come to in creating an institutional framework for addressing the case by case recognition of the existence of Aboriginal and treaty rights. 
best interests of its beneficiary so as to benefit another interest. ${ }^{14}$ More than a decade ago, the Supreme Court of Canada used this logic to establish that an appropriate measure of infringement upon existing Aboriginal fishing rights required consultation by the Crown in order to be correctly determined. ${ }^{15}$ More recently, the Court has declared that an exercise of the Crown's public duty may trigger its fiduciary duty to Aboriginal people. When triggered, the duty is appropriately exercised if the affected Aboriginal interest is not absolutely protected, as it would be under normal fiduciary principles, but only subject to "minimum impairment." 16

The judicial review of administrative action is similarily grounded in history. For more than eight centuries, ${ }^{17}$ the prerogative writs and their statutory successors have dealt with relations between Crown servants and Crown subjects. Hundreds of years ago, the common law established that a person's rights ought not to be abrogated without benefit of the procedural protections of natural justice - audi altarum partem and nemo judex in causo suo (it is fair that the other party be heard and that discretion should be exercised in a disinterested unbiased manner). ${ }^{18}$ Modern administrative law has broadened and deepened the natural justice concept into the modern common law doctrines of procedural fairness and the unreasonable exercise of power which require the Crown, in a broad range of circumstances, to follow fair procedures and to exercise reasonable discretion when it affects the rights of the Crown's subjects. ${ }^{19}$ These jurisprudentially well-developed doctrines sufficiently parallel the procedural and substantive aspects of the Crown's duty to consult and accommodate Aboriginal people, in order to act as a familiar guide to practitioners and the courts in fleshing out when and how the Crown should consult Aboriginal people.

The general administrative law analogy provides an insight into the proper method to study the Crown's duty to consult Aboriginal people. Any brief perusal of the chapters on the doctrines of procedural fairness and the improper exercise of discretionary powers in a modern administrative law text ${ }^{20}$ demonstrates that: (i) the categories of interactions between the Crown and its subjects are almost numberless and not closed; and (ii) such interactions often lead the Crown's subjects to turn to the courts to question whether their treatment by the Crown has been fair. Common sense provides a third conclusion. A small minority of administrative decisions are subjected to judicial review. This is likely due to the fact that there is much law to guide the makers of administrative decisions, as well as specialized governmental institutions created to deal expertly with specialized problems.

The Crown's interactions with its Aboriginal subjects in respect of Aboriginal and treaty rights follow the pattern of (i) and (ii) above, but because the Crown often fails to meet its

$14 \quad$ Hanbury \& Maudlsey, supra note 5 at 282.

Supra note 1.

Osoyoos Indian Band v. Oliver (Town), [2002] 1 W.W.R. 23 (S.C.C.).

Pollock \& Maitland, supra note 5.

S. de Smith, Lord Woolf \& J. Jowell, Judicial Review of Administrative Action, 5 th ed. (London: Sweet \& Maxwell, 1995) at 377-84.

19 Ibid. at 394. See also S. Blake, Administrative Law in ('anada, 3d ed. (Toronto: Butterworths, 2001) at 12 .

20) de Smith, ibid. at 375-607, and Blake, ibid. at 12-22, 89-108. 
duty to consult Aboriginal people, our common sense conclusion does not yet apply to otherwise justifiable Crown infringements of Aboriginal and treaty rights.

While advancing the theory that general administrative law can elucidate the consultation doctrine of Aboriginal law, the more one appreciates the reason for that doctrine's development in the courts, the more one understands that the judiciary has given more thought and attention to the right relationship between the Crown and its Aboriginal subjects than has the Crown itself. Given equal attention by government, with its broad legislative powers, it might be possible to institutionalize fair dealing in circumstances of potential infringement.

\section{A. Procedural Fairness}

Over the last few decades, Anglo-Canadian administrative law has significantly broadened the application of the doctrine generally known as "natural justice." The common law right to natural justice suffered much narrowing in the first half of the twentieth century when judicial balancing of the effects of the Crown's acts upon the interests of its subjects was influenced by successive international and national emergencies and the resulting concerns for economy of process and national security inherent in such circumstances. ${ }^{21}$

Since the decision by the House of Lords in Ridge v. Baldwin, ${ }^{22}$ and the decision by the Supreme Court of Canada in Nicholson v. Haldimand-Norfolk (Regional Municipality) Commissioners of Police, ${ }^{23}$ the old common law right to natural justice has evolved into the duty of procedural fairness. Today Canadian courts require that the Crown demonstrate that it has acted fairly in affecting the rights of the subject in a very wide range of administrative practices.

In her text, Sara Blake stated the minimum indicia of fair procedure as follows:

At a minimum, the doctrine of fairness requires that, before a decision adverse to a person's interests is made, the person should be told the case to be met and be given an opportunity to respond. The purpose is twofold. First, the person to be affected is given an opportunity to influence the decision. Second, the information received from that person, should assist the decision maker to make a rational and informed decision. A person is more willing to accept an adverse decision if the process has been fair. A right to be heard does not imply a right to have one's views accepted nor does it encompass a right to be granted the order sought. It is only a right to have one's views heard and considered by the decision maker. ${ }^{24}$

In effect, the common law has expanded from the doctrine of natural justice to a doctrine which, to a great extent, runs parallel with the guarantees of rights and freedoms contained in Canada's Constitution. The doctrine of procedural fairness is subject to statute, and like all doctrines of the common law, meets its limits, and in appropriate circumstances must cede 
its cause either to the action of the constitutional tests of statutory validity or to statutory amendment.

Fairness is determinable by an objective test which takes into account the circumstances of each case. What is objectively fair in one case is not necessarily fair in another. The courts have considerable expertise and jurisprudential guidance in determining when the Crown has acted fairly and when it has not. The spectrum of fair treatment runs from informal discussion to formal proceedings differing little from a formal trial. One circumstance which may have an influence on what is fair is a cost-benefit analysis of the incremental value of more elaborate processes. $^{25}$

In Baker v. Canada (Minister of Citizenship and Immigration), ${ }^{26}$ the Supreme Court of Canada listed five factors to be considered in determining the appropriate procedure for achieving fairness in the circumstances of any particular infringement of a Canadian's rights, other than Aboriginal and treaty rights. First, courts must consider the nature of the decision and the process followed in making it. Acts of the Crown that are legislative or political and affect the community as a whole are generally not subject to the duty of procedural fairness, while those turning on questions of fact and law and affecting smaller groups or an individual attract the duty. Statutorily prescribed procedures may vary from procedures closely analogous to civil trials, to only the loosest procedural directions. Generally, the closer to the trial model, the greater the need for fairness. Decisions based on discretion and policy should have procedures appropriate to the bureaucratic framework in which they are to be made. Second, the common law duty of procedural fairness cannot override a statutory procedure. Third, courts must consider the importance of the decision for the affected subject. Once again, the more important the interest, the more closely the procedure should approximate the civil trial model. Notably, the common law treats interests in property and in the obtaining of a livelihood as interests of great importance. Fourth, courts must consider the legitimate expectations of the parties. If the Crown has represented that some procedure will be followed, the subjects to whom the representation has been made will have a legitimate expectation that such procedure be followed and may rightly complain in its absence that the Crown has not acted fairly in defeating legitimate expectations. Fifth, the courts will defer to fair procedures created by tribunals to deal with the circumstances of any particular case. Tribunals must have the latitude to act properly, and so long as what they do is fair and consistent, the courts tend to accept that they have acted fairly.

A brief reflection on the applicability of the five Baker principles to the determination of appropriate procedures in fulfilling the Crown's duty to consult Aboriginal people shows that the underlying principles of the duty of procedural fairness must be instructive as regards the procedural content of the duty to consult Aboriginal people.

Aboriginal Canadians are as entitled to benefit from the common law doctrine of procedural fairness as are any other Canadians. Where the Crown infringes on the interests of Aboriginal people that are not interests amounting to an existing Aboriginal or treaty right

26. [1999] 2 S.C.R. 817 [Baker]. 
and such infringement is not through legislation but under a procedure involving the Crown's duty of procedural fairness, the affected Aboriginal people will be entitled to the benefit of such duty, and the appropriate manner of its exercise would be determined under the Baker principles. To the extent that such interests of Aboriginal people are infringed in a manner contrary to the guarantees of the Constitution of Canada, the Constitution will render legislative or other acts of the Crown invalid. ${ }^{27}$

If the actions of the Crown infringe an existing Aboriginal or treaty right, such infringement would force the Crown to justify the infringement as appropriate and reasonable in the circumstances - in effect, to prove that it is fair. This would require that the Crown effect an appropriate and procedurally fair consultation in order to meet its duty to consult. The duty to consult requires not only that the procedure be fair, but that the result of the consultation be correct. This stands in stark contrast to the duty of procedural fairness which allows the courts to strike down the right determination resulting from the wrong procedure and will allow the courts to let the wrong determination stand if the procedure followed is that stipulated in statute or if it is demonstrably fair.

\section{B. Substantive Tests}

While the Crown's duty to consult Aboriginal people consists of both procedural aspects (for example, procedural fairness) and substantive aspects (for example, accommodation and mitigation of impacts of infringements), to date the courts have found administrative decisions relating to consultation in the context of infringements of existing Aboriginal and treaty rights to be inappropriate on the basis of procedural errors. However, as the timing and content of proper consultation with Aboriginal people becomes more widely understood by all stakeholders, and as the Crown masters appropriate consultation procedures, it is to be expected that some administrative decisions resulting from consultation and purporting to justify infringement of existing Aboriginal or treaty rights will be challenged under one or more of the doctrines known to general administrative law relating to the substantive nature of the Crown's determination.

Administrative law principles could be used to challenge proposed accommodation resulting from consultation in a myriad of ways. ${ }^{28}$ The accommodations could be challenged as irrational; as exceeding the discretionary powers provided in the governing legislation; as resulting from bad faith or discrimination; as fettering the discretion of the tribunal by imposing an overly restrictive application of the consultation guidelines; or as capitulating to political dictation. ${ }^{29}$ This brief list demonstrates what may lie ahead in the courts. Recognizing what can be challenged is necessary to avoid successful challenges to decisions after an appropriate procedure has been followed in a consultation to justify an infringement.

Section 52(1) of the Constitution Act, 1982, supra note 11 states: "The Constitution of Canada is the supreme law of Canada, and any law that is inconsistent with the provisions of the Constitution is, to the extent of the inconsistency, of no force or effect." 


\section{Consultation and Aboriginal People}

\section{A. JUdiCIAL ORIGINS}

The duty of the Crown to consult Aboriginal people arises when governmental activities, decisions or legislation interfere with and infringe existing Aboriginal and treaty rights. The Supreme Court of Canada's decisions in Sparrow, ${ }^{30}$ Delgamuukw ${ }^{31}$ and other cases ${ }^{32}$ at various levels of court have confirmed that the duty of the Crown to consult with Aboriginal people requires a fundamental shift in the way the Crown has traditionally interacted with Aboriginal people. As a result of the influence of Delgamuukw and other judicial decisions, some governments have attempted to enhance their consultation policies and mechanisms. Unfortunately, these attempts by governments to create better consultation regimes have not yet resulted in the expected stability with respect to governmental decision-making or predictability regarding the outcome once an attempt at consultation is made. The discussion below examines the case law to date on Crown-Aboriginal consultation and outlines practical considerations for governments so they may to ensure that their Aboriginal consultation schemes will withstand judicial scrutiny and result in stability and predictability for Aboriginal people, governments and industry.

\section{B. SOURCE OF THE DUTY TO CONSULT}

Although most of the judicial focus to date regarding the source of the Crown's duty to consult has been within the context of the justification analysis for Crown infringements of existing Aboriginal and treaty rights recognized and affirmed by s. 35(1) of the Constitution $A c t, 1982,{ }^{33}$ the case law and Canadian law generally suggests three other sources, for a total of at least four sources for the Crown's duty to consult Aboriginal people:

(1) the right of all persons under Canadian law to be dealt with by the Crown in a manner that is procedurally fair and reasonable and in accordance with the common law procedural and substantive elements of administrative law;

(2) the Crown's sui generis fiduciary relationship with Aboriginal people requires the fiduciary (the Crown), in equity, to consult with and consider the views of the beneficiary (Aboriginal people), where such circumstances invoke the fiduciary relationship;

(3) the "honour of the Crown"; and

(4) the analysis to be used when considering the justification of Crown infringements under s. 35(1) of the Constitution Act, 1982.

Supra note 1 at 1113, 1119; see also A. Knox \& T. Isaac, "Canadian Aboriginal Law: Creating Certainty in Resource Development" in Mining Law and Investment in Latin America, Manual to a conference held 24 April 2003, Paper No. 9 (Westminster, Co.: Rocky Mountain Mineral Law Foundation, 2003).

31 Delgamuukw, supra note 4 at para. 68.

32 R. v. Marshall II, [1999] 3 S.C.R. 533 at paras. 43-44; R. v. Nikal, [1996] I S.C.R. 1013 at para. 110; R. v. Van der Peet, [1996] 2 S.C.R. 507 at para. 311 (McLachlin J. dissenting); Mikisew Cree First Nation v. Canada (Minister of Canadian Heritage), [2002] 1 C.N.L.R. 169 at para. 130 (F.C.T.D.); and Nunavik Inuit v. Canada (Minister of Canadian Heritage), [1998] 4 C.N.L.R. 68 at paras. 107-109 (F.C.T.D.).

$33 \quad$ Supra note 11. 
In $R . v$. Guerin, ${ }^{34}$ Dickson J. described the fiduciary obligations of the Crown to Aboriginal people in the following manner:

\footnotetext{
Where by statute, agreement, or perhaps by unilateral undertaking, one party has an obligation to act for the benefit of another, and that obligation carries with it a discretionary power, the party thus empowered becomes a fiduciary. Equity will then supervise the relationship by holding him to the fiduciary's strict standard of conduct.... in this sui generis relationship, it is not improper to regard the Crown as a fiduciary. ${ }^{35}$
}

In Delgamuukw, ${ }^{36}$ the Supreme Court of Canada began its discussion of the Crown's duty to consult by noting that the fiduciary relationship between the Crown and Aboriginal people may be satisfied "by the involvement of Aboriginal peoples in decisions taken with respect to their lands." ${ }^{37}$ Note the use of the word "involvement," rather than, for example, the word "approval" or "veto," and the use of the word "may" rather than "must." This demonstrates, once again, the Supreme Court of Canada's attempt to set out an analytical framework for interpreting Aboriginal and treaty rights that is not absolute, but which affords these rights adequate and fair treatment by governments.

\section{Triggering THE DutY To CONSUlt}

Presently, there is a judicial conflict with respect to when the Crown's duty to consult Aboriginal people is triggered. The Supreme Court of Canada has made reference to the duty to consult within the context of the justification analysis of s. 35(1) of the Constitution Act, 1982, thereby requiring Aboriginal and treaty rights to be proven (or existing) prior to the duty to consult being engaged. In Sparrow, ${ }^{38}$ the Supreme Court of Canada held that consultation forms an important component of the analysis utilized by the Crown to justify an infringement of an existing Aboriginal or treaty right under s. 35(1). Chief Justice Dickson stated that whether the Aboriginal group at issue had been consulted is one of the further questions courts are to ask when determining whether the Crown's infringement of an Aboriginal or treaty right is justified. ${ }^{39}$ Within this context, the duty to consult Aboriginal people has generally been seen as a duty that arises once an Aboriginal or treaty right is deemed to be existing or not extinguished within the meaning of s. 35(1) of the Constitution Act, 1982.

In Ontario (Minister of Municipal Affairs and Housing) v. Trans-Canada Pipelines, ${ }^{40}$ the Ontario Court of Appeal affirmed that consultation is not an independent right held by Aboriginal people, but rather attaches to already existing Aboriginal and treaty rights. ${ }^{41}$ 
Similarly, in commenting on Sparrow, ${ }^{42} R . v$. Badger, ${ }^{43}$ and Delgamuukw, ${ }^{44}$ the Ontario Court of Appeal in Trans-Canada Pipelines noted that:

What these cases decide is that the duty of the Crown to consult with First Nations is a legal requirement that assists the court in determining whether the Crown is constitutionally justified in engaging in a particular action that has been found to prima facie infringe an existing Aboriginal or treaty right of a First Nation. It is only after the First Nation has established such infringement through an appropriate hearing that the duty of the Crown to consult with First Nations becomes engaged as a factor for the court to consider in the justificatory phase of the proceeding. ${ }^{45}$

In two recent decisions, Taku River ${ }^{46}$ and Haida ${ }^{47}$ the British Columbia Court of Appeal has held that the duty to consult can arise absent a proven Aboriginal or treaty right. Both decisions affirmed that the duty to consult can be engaged, absent a proven Aboriginal or treaty right, in cases where an Aboriginal right prima facie appears to exist, or more generally as a fundamental component of procedural fairness when the Crown acts in circumstances where decisions or legislation are likely to have an impact upon Aboriginal interests.

In Haida, Lambert J.A., for the Court, considered the issue of whether the duty to consult arises absent a proven Aboriginal right, and concluded that even if no conclusive determination of a right has been made:

it does not mean that there is no fiduciary duty on the Crown to consult the Aboriginal people in question after title is asserted and before it is proven to exist, if, were title to be proved, there would be an infringement.

How could the consultation aspect of justification test with respect to a prima facie infringement be met if the consultation did not take place until after the infringement? By then it is too late for consultation about that particular infringement. By then, perhaps, the test for justification can no longer be met and the only remedies may be a permanent injunction and compensatory damages. ${ }^{48}$

The Court of Appeal appeared to suggest that in order for the duty of the Crown to consult Aboriginal people to be understood and to have a meaningful interpretation, the consultation must occur before infringement and, therefore, prior to any reasonable ability by the Aboriginal group in question to be able to prove their claimed Aboriginal rights or Aboriginal title.

Justice Lambert also noted that the particular circumstances relating to the claims of the Haida Nation amount to a "good prima facie case" to support the duty to consult, absent a proven Aboriginal right:

Supra note 1.

[1996] 1 S.C.R. 771 [Badger].

Supra note 4.

Supra note 40 at para. 119.

Taku River, supra note 3.

Haida, supra note 3.

Ibid. at paras. 41-42. 
The strength of the Haida case gives content to the obligation to consult and the obligation to seek an accommodation. I am not saying that if there is something less than a good prima facie case then there is no obligation to consult. I do not have to deal with such a case on this appeal. But certainly the scope of the consultation and the strength of the obligation to seek an accommodation will be proportional to the potential soundness of the claim for Aboriginal title and Aboriginal rights. ${ }^{49}$

The British Columbia Court of Appeal confirmed that the duty to consult and to accommodate reasonably does not arise solely from the s. 35(1) justification test. It also arises from the "broader fiduciary footing of the Crown's relationship with the Indian peoples who are under its protection." 50

This broader basis for the Crown's duty to consult Aboriginal people is most likely based in part on the Crown's fiduciary relationship with Aboriginal people and in part on the Crown's general duty to treat its subjects fairly when acting or determining issues likely to have an impact upon them. This latter basis for the duty to consult, namely procedural fairness and the substantive requirements of administrative law, would exist regardless of s. 35(1). However, because of s. 35(1) Aboriginal and treaty rights, the Crown's fiduciary relationship with Aboriginal people, and the "honour of the Crown," the courts have paid special attention to the Crown's duty to treat Aboriginal people fairly, to take their rights seriously and to consider the impact of Crown decisions, actions and legislation on the rights of Aboriginal people.

The duty to consult is engaged by administrative law principles, the fiduciary relationship between Aboriginal people, the "honour of the Crown," and the justification analysis under s. 35(1). The courts are not clear on the question of when the duty to consult is engaged. Some governments take the restrictive view that they are not obligated to consult Aboriginal people until an Aboriginal right has been proven. While this remains an interesting legal issue, its practical implications for governments have not been positive, as successive decisions of courts in Canada have held governments to a high standard when it comes to dealing with the rights of Aboriginal people. Until this matter is settled by the Supreme Court of Canada, governments should cautiously adopt a broad approach when consulting Aboriginal people to ensure that the potentially infringing actions and decisions of governments can withstand judicial scrutiny under s. 35(1). This approach would be consistent with the Supreme Court of Canada's decision in R. v. Côté, ${ }^{\text {s1 }}$ where the Court noted that:

Section 35(1) only lays down the constitutional minimums that governments must meet in their relations with Aboriginal peoples with respect to Aboriginal and treaty rights. Subject to constitutional constraints, governments may choose to go beyond the standard set by s. $35(1) .^{52}$

Clearly, with respect to the issue of consultation, governments should look to the courts only for minimal guidance, rather than for all the answers to solve these issues. Time and time

Ibid. at para. 51 [emphasis added].

Ibid. at para. 55.

[1996] 3 S.C.R. 139 [Côté].

Ibid. at para. 83 [emphasis added] 
again, governments in Canada have come up short on their ability to meet the standards imposed by the courts due to lack of understanding or lack of resources, or by taking a minimalist perspective when implementing judicial decisions. To ensure that their decisions can withstand judicial scrutiny under s. 35(1), governments should go beyond the minimum standard set out therein, particularly with respect to consultation, where the appropriate standard will vary from situation to situation and Aboriginal group to Aboriginal group. To do otherwise tends to prove penny-wise and pound foolish.

\section{Nature OF The Duty To Consult}

In Delgamuukw, ${ }^{53}$ Lamer C.J.C. stressed the importance of consultation by the Crown with Aboriginal people regarding decisions, actions and legislation of the Crown which may infringe Aboriginal title:

There is always a duty of consultation.... The nature and scope of the duty of consultation will vary with the circumstances. In occasional cases, when the breach is less serious or relatively minor, it will be no more than a duty to discuss important decisions that will be taken with respect to lands held pursuant to Aboriginal title. Of course, even in these rare cases when the minimum acceptable standard is consultation, this consultation must be in good faith, and with the intention of substantially addressing the concerns of the Aboriginal peoples whose lands are at issue. In most cases, it will be significantly deeper than mere consultation. Some cases may even require the full consent of an Aboriginal nation, particularly when provinces enact hunting and fishing regulations in relation to Aboriginal lands. ${ }^{54}$

Three basic categories of consultation with Aboriginal people appear to emerge. First, there is the "occasional," "rare" or "mere consultation" which must occur with the intention to address the concerns of Aboriginal people. In effect, "consultation" in its least technical definition is talking together for mutual understanding. This "mere consultation" may involve some discussion between the Crown and the Aboriginal group affected, with the Crown responding to concerns raised. Second, in most cases something "significantly deeper than mere consultation" will be required. Little guidance is provided by the Supreme Court of Canada on what this category means. While it involves participation in the decision-making process, it most likely does not extend to the upper reaches of consultation which includes "consent." This middle ground of consultation probably includes a duty on the Crown to accommodate the interests of Aboriginal people, discussed in more detail below. Third, at the end of the consultation spectrum is consultation amounting to the required "consent" of the Aboriginal group involved, which may be tantamount to a veto. ${ }^{55}$

It is interesting that these three categories of Aboriginal consultation correspond closely with the spectrum of possible fair procedures under the doctrine of procedural fairness. Like Lamer C.J.C. in Delgamuukw, ${ }^{56}$ de Smith states that "mere consultation" is at the lower end of the spectrum of fair procedures. ${ }^{57} \mathrm{He}$ also notes that a full hearing (Lamer C.J.C. uses the

53. Supra note 4.

$54 \quad$ Ibid. at para. 168 .

ss R. v. Aleck, [2001] 2 C.N.L.R. 118 (B.C. Prov. Ct.), provides an example of where the issue of Indian band consent was explicitly considered and rejected.

56. Supra note 4.

57 Supra note 18 at 431. 
word "consent") is at the other end of the spectrum. In the middle lies the bulk of the content of fair procedures, namely the entitlement to make written and oral representations and to have such representations meaningfully considered. In the case of Aboriginal people, consideration most likely also includes attempting to accommodate Aboriginal peoples' interests, including such measures as mitigating the negative aspects of justifiable infringements on existing Aboriginal and treaty rights and attempting negotiated solutions, where appropriate. Indeed, on the use of the word "consultation," de Smith writes that:

terms such as "consultation" need elaboration and degrees of disclosure or candour will differ in different circumstances.... [W] here a large-scale consultation has been carried out, the courts may be effectively powerless to ensure that representations have been read and digested — unless the decision-maker is required to address representations received by way of reasons. Furthermore, where consultations are invited upon detailed proposals which have already been arrived at, the duty of the court to ensure that genuine consideration has been given to critical representations is taxed to the utmost. ${ }^{58}$

In $R$. v. Marshall, ${ }^{59}$ the Supreme Court of Canada reaffirmed the importance of consultation within the context of treaty rights:

The Court has emphasized the importance in the justification context of consultations with Aboriginal peoples.... This special trust relationship includes the right of the treaty beneficiaries to be consulted about restrictions on their rights, although, as stated in Delgamuukw, supra, at para. 168: "The nature and scope of the duty of consultation will vary with the circumstances." This variation may reflect such factors as the seriousness and duration of the proposed restriction, and whether or not the Minister is required to act in response to unforeseen or urgent circumstances. As stated, if the consultation does not produce an agreement, the adequacy of the justification of the government's initiative will have to be litigated in the courts. ${ }^{60}$

In Marshall $I I,{ }^{61}$ the Supreme Court of Canada appeared to suggest that agreements between Aboriginal people and the Crown can satisfy the requirement to maintain the principles associated with the special trust relationship between them. Additionally, the scope and extent of consultation varies from case to case and depends, in part, on factors associated with the "seriousness and duration" of the interference with the rights of Aboriginal people.

Related closely to the concept of Aboriginal consultation and, indeed, forming a part of that consultation, are the principles of accommodation and prioritization. The Supreme Court of Canada in R. v. Gladstone ${ }^{62}$ stated that the following issues are relevant to whether the Crown has granted priority to, and has accommodated, Aboriginal rights:

(a) whether the government has accommodated the exercise of the Aboriginal right;

Ibid. at $431,440-41$.

[1999] 3 S.C.R. 456 [Marshal], reconsideration refused, [1999] 3 S.C.R. 533 [Marshall II]. For a discussion of the role of the Crown in implementing the Marshall decision, see T. Isaac, "The Courts, Government, and Public Policy: The Significance of R. v. Marshall' (2000) 63 Sask. L. Rev. 701, and T. Isaac, Aboriginal and Treaty Rights in the Maritimes: The Marshall Decision and Beyond (Saskatoon: Purich, 2001).

Marshall II, ibid. at para. 43.

Ibid.

[1996] 2 S.C.R. 723 [Gladstone]. 
(b) whether the objectives of government by enacting a particular regulatory scheme reflect the need to consider the Aboriginal priority;

(c) the extent of participation in the fishery, in the case of fishing rights, by Aboriginal people relative to their proportion of the population;

(d) how government has accommodated different Aboriginal rights (the right to fish for food and the right to fish commercially);

(e) how important the right is to the economic and material well-being of the Aboriginal group claiming the right; and

(f) the criteria used by government to allocate the particular resources at issue. ${ }^{63}$

Apart from the issue of priority, other questions raised under this component of the Sparrow justification analysis include the following: ${ }^{64}$

(a) Has there been as little infringement as possible in order to effect the desired result?

(b) In expropriation, has fair compensation been paid?

(c) Has the Aboriginal group been consulted with respect to the conservation measures used, or at least have they been informed of these conservation measures?

The British Columbia Court of Appeal noted in Halfway River First Nation v. British Columbia (Minister of Forests) that the "fact that adequate notice of an intended decision may have been given, does not mean that the requirement for adequate consultation has also been met." ${ }^{\prime 65}$ In Delgamuukw, Lamer C.J.C. described the concept of priority as applied to Aboriginal title in the following manner:

If the Crown fiduciary duty requires that Aboriginal title be given priority, then it is the altered approach to priority that I laid down in Gladstone which should apply... [T] his might entail, for example, that governments accommodate the participation of Aboriginal peoples in the development of the resources of British Columbia. $^{66}$

Interestingly, the above excerpt from Delgamuukw is one paragraph before Lamer C.J.C.'s discussion of consultation and Aboriginal title. This excerpt provides a basis for the Supreme Court of Canada's overall analytical thrust in balancing the rights of Aboriginal people with the ability of governments to govern. While different words are used, such as "accommodation," "priority" and "consultation," they all seek a non-absolute interpretation to Aboriginal and treaty rights that is fair and balanced. At their core, all these words and concepts possess a procedural and substantive element.

Thus, consultation in the Aboriginal context can be said to possess both procedural and substantive elements. Procedurally, Aboriginal people must be given an opportunity to have their views heard and considered in a manner similar to that required by the law relating to procedural fairness. Substantively, Aboriginal people must have their rights accommodated, which may include mitigation of harmful impacts on Aboriginal rights, minimal impairment

64 Supra note 1 at 1119. See also Badger, supra note 43 at para. 84 and Gladstone, supra note 62 at para. 55. 
of Aboriginal rights or attempting negotiated solutions, as the case may be. If consultation does not produce an agreement, the adequacy of the Crown's justification and consultation efforts may be litigated in the courts. ${ }^{67}$ In effect, the "consent" of Delgamuukw and the "judicial hearing" of de Smith become the same thing.

In Sparrow, ${ }^{68}$ the Supreme Court of Canada affirmed its general approach regarding the Crown's fiduciary obligations to Aboriginal people first outlined in Guerin $^{69}$ by stating that the scrutiny to be applied to federal and provincial legislative authority under s. 35(1) is in keeping with "the concept of holding the Crown to a high standard of honourable dealing."70 In the end, this forms a core element of the duty to consult: honourable dealing by the Crown.

The critical issue for governments is the extent to which they are prepared to satisfy their consultation duties within the ambit of Aboriginal rights, Aboriginal title, and treaty rights. Addressing this issue is not an easy task, but can in part be ameliorated by governments establishing consistent, thorough and pan-governmental standards and policies, institutionalized or otherwise, regarding consultation with Aboriginal people. Such standards and policies, fairly conceived, should establish a predictable level of judicial deference for Crown action in justifiable infringements of Aboriginal and treaty rights so as to relieve the myth that Canada's natural resource base is burdened with an "Aboriginal problem."

The nature of these issues is that they require a case-by-case analysis and, in many respects, a subjective approach to what does and does not require consultation, and to what degree consultation must occur. This is one aspect of what makes consultation with Aboriginal people particularly difficult for large institutions, such as government, to implement in a vast multi-jurisdictional country like Canada.

\section{E. Duty of Aboriginal People not to Frustrate the Consultation}

Aboriginal people have an obligation not to frustrate attempts by the Crown to consult with them. In Halfway River, ${ }^{71}$ the Court of Appeal considered the duty owed by the Ministry of Forests to consult with the Halfway River First Nation [Halfway] over various cutting decisions made by the Ministry. The Court commented on the nature of the Crown's duty to consult within the context of Treaty 8 and affirmed that the Ministry had a duty to consult Halfway prior to making decisions that might affect Aboriginal and treaty rights. It was noted that the Ministry failed to take all reasonable efforts to consult with, and inform itself about, Halfway.

The Court also stated that the Ministry failed to the give Halfway relevant information relating to decisions being made. While relevant information must be provided to Aboriginal people in a timely manner and their representations taken seriously by government, Aboriginal people also have a duty not to frustrate or obstruct the consultation process by refusing to participate or by placing unreasonable conditions on government:

Marshall II, supra note 59 at para. 43.

Supra note 1.

Supra note 34.

Supra note 1 at 1109.

Supra note 65. 
The fact that adequate notice of an intended decision may have been given, does not mean that the requirement for adequate consultation has also been met.

The Crown's duty to consult imposes on it a positive obligation to reasonably ensure that Aboriginal peoples are provided with all necessary information in a timely way so that they have an opportunity to express their interests and concerns, and to ensure that their representations are seriously considered and, wherever possible, demonstrably integrated into the proposed plan of action....

There is a reciprocal duty on Aboriginal peoples to express their interests and concerns once they have had an opportunity to consider the information provided by the Crown, and to consult in good faith by whatever means are available to them. They cannot frustrate the consultation process by refusing to meet or participate, or by imposing unreasonable conditions. ${ }^{72}$

This statement clearly places a duty not only on the Crown, but also on Aboriginal people. Aboriginal people, in becoming attuned to what rights they possess by way of treaty, Aboriginal title or otherwise, must also be attuned to the corresponding duties. Thus, like public governments, Aboriginal people need to develop processes by which they manage government consultation and referrals. Aboriginal people will also want to become engaged in establishing the appropriate administrative, legal and other mechanisms necessary to fully respond to governments' consultation requests. This necessary work can be a daunting task for many Indian bands that do not have adequate resources.

In Kelly Lake First Nation v. British Columbia ${ }^{73}$ the Crown was found not to have an obligation to consult, and if there was such an obligation, it had not been met when the Kelly Lake First Nation failed to provide any response to the Crown's letter following discussions between the Crown and the Indian band. Justice. Taylor also noted that the decision-maker for the Crown in this case took into consideration potential Aboriginal and treaty rights that may be affected:

The process of consultation cannot be viewed in a vacuum and must take into account the general process by which government deals with First Nations people, including any discussions between resource developers such as Amoco and First Nations people.... It was submitted that the SFN [Saulteux First Nation] were without the resources to provide information unless requested. The evidence, while establishing that this community of First Nations is of limited means does not establish a community incapable of providing the information sought.... In conclusion, while the SFN as represented by Chief Cameron are adamant in their opposition to this project, they have been afforded the fulfilment of the duty upon the Crown to be consulted. Any responsibility for the absence of consultation lies with their own representatives. ${ }^{74}$

This so-called requirement not to "frustrate" the consultation process is simply another example of the courts imposing a level of reasonableness on the overall relationship between the Crown and Aboriginal people and their rights. Another issue is whether there is a legal requirement on the Crown to fund consultation processes involving Aboriginal people. From

72 Ibid. at para. 159-61. The Ontario Court of Appeal felt that the onus on Indian bands not to frustrate the consultation process, as enunciated in Halfivay River, had "considerable merit"; see supra note 40 at para. 123.

$73 \quad$ [1999] 3 C.N.L.R. 126 (B.C.S.C.).

74 Ibid. at paras. $154,244,252$ [emphasis added] 
the perspective of achieving certainty and stability with respect to dealing with these matters, it would seem that governments have a vested interest in ensuring that their consultation guidelines and schemes are fully implemented. This may require the expenditure of resources, which can easily be justified in light of the growing litigation costs over these matters and the increasing degree of business uncertainty that has been created and which will exist until all parties trust the consultation process to be, in most cases, objectively fair.

\section{F. Case Law: Procedural ERrors}

Cheslatta Carrier Nation v. British Columbia ${ }^{75}$ provides a useful example of where the Crown failed to meet its duty to consult. Insufficient information was possessed by the Government of British Columbia to assess adequately the potential impact on Aboriginal rights and, therefore, did not allow the Cheslatta Carrier Nation to mount a proper defence to the proposed action. This decision of the British Columbia Supreme Court was based primarily on a separately established statutory duty to consult outlined in British Columbia's Environmental Assessment Act. ${ }^{76}$

In Trans-Canada Pipelines, ${ }^{77}$ the Ontario Court of Appeal considered an order made by a commission under Ontario's Municipal Act ${ }^{78}$ to amalgamate a number of townships into a single municipality. A number of First Nations sought a declaration that the order infringed hunting, fishing and trapping rights guaranteed in Treaty 9 and could impede future land claims negotiations. The lower court allowed the applications for judicial review. The Court of Appeal allowed the appeal, thereby confirming the original order creating a single municipality. One argument upon which the lower court rested its decision, and which the Court of Appeal carefully addressed, concerned the issue of whether the Crown failed to consult with the Indian bands. The Court of Appeal held that the commission did not lose its jurisdiction when it failed to consult with the relevant Indian bands. The Municipal Act places no statutory duty on the commission to consult. The Court of Appeal also affirmed that the Crown's duty to consult Aboriginal people is only engaged when a particular action of the Crown has been found to be a prima facie infringement of an existing Aboriginal or treaty right ${ }^{79}$ thereby contradicting the British Columbia Court of Appeal decisions in Taku River $^{80}$ and Haida ${ }^{81}$ where a good prima facie case regarding the potential existence of Aboriginal title was sufficient to engage the Crown's duty to consult and accommodate Aboriginal people. ${ }^{82}$

In Liidlii Kue First Nation v. Canada ${ }^{83}$ the Federal Court, Trial Division, considered an application by the Liidlii Kue First Nation seeking a declaration that the Crown breached its fiduciary duty to consult them prior to issuing a land use permit (by a land use administrator).

[1998] 3 C.N.L.R. 1 (B.C.S.C.).

R.S.B.C. 1996 , c. 119.

Supra note 40.

R.S.O. 1990, c. M-45 [Municipal Act].

Ibid. at para. 119.

Taku River, supra note 3.

Haida, supra note 3.

Ibid.

[2000] 4 C.N.L.R. 123 (F.C.T.D.). 
The Court refused to grant the declaratory relief, but did send the matter back to a different land use administrator. The Court confirmed that there exists a constitutional duty to consult with those exercising the Treaty 11 rights to hunt, trap and fish on unoccupied Crown lands. The Court also affirmed that such Crown duty to consult and the standard required will vary from case to case.

In Haida, Lambert J.A. stated that the roots of the Crown's duty to consult come from the special trust-like or fiduciary relationship between the Crown and Aboriginal people. ${ }^{84}$ Justice Lambert stated that this duty to consult is owed by both the federal and provincial Crowns, and when the duty arises, it must be exercised as a duty of "utmost good faith." 85 When looking to find a rational legal basis for requiring consultation when it appears that prima facie rights will be impugned, the appropriate measure of the Crown's duty to consult should not be so onerous as an "utmost good faith" standard.

The only time the Supreme Court of Canada used the phrase "utmost good faith" within the context of the Crown's fiduciary relationship with Aboriginal people was in Québec (A.G.) v. Canada (National Energy Board) ${ }^{86}$ However, it did so only with respect to certain procedural elements of the decision-making process of the National Energy Board (NEB). The Court determined, within the context of a duty of "utmost good faith," that the NEB did not owe a duty to Aboriginal people to make full disclosure or to make decisions in the "best interests" of Aboriginal people. ${ }^{87}$ Keeping in mind the very high standard implicit in a duty of "utmost good faith," and the fact that the Supreme Court of Canada has never stated that the Crown's fiduciary duty to consult with Aboriginal people was of such a high order, it is questionable whether "utmost good faith" would be upheld as the appropriate measure of the Crown's duty to consult with Aboriginal people.

The Crown's fiduciary relationship with Aboriginal people does not always give rise to a corresponding fiduciary duty, and the fiduciary relationship between the Crown and Aboriginal people is not endless in scope. In Hydro-Québec, a unanimous nine-member panel of the Supreme Court of Canada stated the following with respect to the Crown's fiduciary relationship with Aboriginal people:

it must be remembered that not every aspect of the relationship between fiduciary and beneficiary takes the form of a fiduciary obligation: Lac Minerals Ltd. v. International Corona Resources Ltd., [1989] 2 S.C.R. 574. The nature of the relationship between the parties defines the scope, and the limits, of the duties that will be imposed. The courts must be careful not to compromise the independence of quasi-judicial tribunals and decision-making agencies by imposing upon them fiduciary obligations which require that their decisions be made in accordance with a fiduciary duty. ${ }^{88}$

Haida, supra note 3 at para. 33 .

85 Ibid. at para. 34. The use of the term "utmost good faith" (uberrimae fidei) is normally used in cases, such as insurance contracts, to describe a necessarily very limited type of contract, in which a first-party fiduciary is presumed to have access to knowledge to which a second-party beneficiary has no access and, therefore, such first party is bound to tell such second-party everything that may likely affect such second-party's judgment. See Courtright v. Canadian Pacific (1983), 4 C.C.E.L. 152 at 162 (Ont. H.C.).

พc [1994] 1 S.C.R. 159 [Hydro-Québec].

87 Ibid. at 184 .

$8 \times \quad$ Ibid. at 183 
Thus, consultation is not required to produce an agreement, but must be "adequate" considering the circumstances in order to support the justification of a governmental infringement of an Áboriginal or treaty right. Litigation may well be the only means by which the parties involved can conclude whether or not the level of consultation in a particular case was "adequate." Consultation is not only a critical component for any government conducting its business, and especially when this business may infringe the rights of Aboriginal people, but is also a key component to a government seeking to justify an infringement of Aboriginal and treaty rights. ${ }^{89}$ However, even with these decisions, there continues to be no clear and consistent definition of what "adequate" consultation means. Rather, the determination of what is adequate consultation depends on a case-by-case analysis, which is consistent with general procedural fairness and integrity of decision-making as contemplated in administrative law. "Appropriate" would ultimately seem to depend upon what is reasonable in the circumstances.

Governments must revisit any regulations that may affect Aboriginal title and Aboriginal and treaty rights to ensure that these regulations provide for reasonable and fair consultation and consideration at the appropriate times. While consultation may not circumvent all of the potential impasses and problems, appropriate consultation measures by government can materially mitigate the current state of uncertainty and instability.

\section{G. The Duty to be FAIR}

The duty to consult can be broken down into two distinct, but interconnected, administrative law concepts: (1) the duty to provide a fair process; and (2) the duty to provide a fair decision. The process is the act of consulting, possibly including notice, information gathering and distribution, discussions with Aboriginal people, and consideration and understanding of the issues and concerns of Aboriginal people. The decision is that part of a government action in which it decides to do or sanction particular activities that may have an impact upon Aboriginal and treaty rights. Like the process, the decision must be seen as being transparent, considered, and arrived at in a manner that ensures that the rights of Aboriginal people were "taken seriously." 90

At one end of the procedural fairness spectrum in general administrative law is, once again, "mere consultation." At the other end is a hearing or a trial. Between these poles is a substantive body of law directing decision-makers on how to act and deal fairly in a broad range of circumstances. Of particular relevance to consultation with Aboriginal people is that "procedural fairness does not, however, guarantee that the exercise of the opportunity to make representations will automatically result in the representations made being accepted." 11 This is supported in the Aboriginal legal context in that existing Aboriginal and treaty rights are not absolute, but may be infringed if governments can justify the infringement in accordance with the tests set out by the courts.

89 In Marshall, the Supreme Court of Canada affirmed that the Sparrow analysis applies to treaty rights cases: see supra note 59 at para. 7: "treaty rights within the meaning of s. 35 .. are subject to regulations that can be justified under the Badger test." See also Badger, supra note 43 at paras. 96-97; Marshall II, supra note 59 at para. 32.

Sparrow, supra note 1 at 1119.

de Smith, supra note 18 at 376. 
The concept of "reasonableness" forms an integral part of the duty to consult under s. 35(1) of the Constitution Act, 1982. According to Cory J. in R. v. Nikal:

It can, I think, properly be inferred that the concept of reasonableness forms an integral part of the Sparrow test for justification.... So too in the aspects of information and consultation the concept of reasonableness must come into play. For example,... a request for consultations cannot simply be denied. So long as every reasonable effort is made to inform and to consult, such efforts would suffice to meet the justification requirement. ${ }^{92}$

The British Columbia Supreme Court has held that there is a duty of procedural fairness when decisions are made that may affect claimed Aboriginal rights. In Westbank First Nation v. British Columbia (Minister of Forests), ${ }^{93}$ the Court considered whether the Crown had a duty to consult prior to established proof of Aboriginal title. The Court held that the provincial Crown's title is encumbered to the extent that Aboriginal title is proven to exist regarding a specific area. The Court also held that, if Aboriginal title is unproven, there is no duty to consult. However, there continues to be an obligation of procedural fairness on the Crown when considering Aboriginal rights claims.

In the English decision of $R$. v. Secretary of State for Social Services, ${ }^{94}$ the Court was asked to determine whether the Secretary of State for Social Services had complied with the statutory duty to consult with certain organizations before enacting regulations under relevant legislation. The Court held that the Secretary of State had failed to fulfil the duty to consult, and stated that:

But in any context the essence of consultation is the communication of a genuine invitation to give advice and a genuine consideration of that advice. In my view it must go without saying that to achieve consultation sufficient information must be supplied by the consulting to the consulted party to enable it to tender helpful advice. Sufficient time must be given by the consulting to the consulted party to enable it to do that and sufficient time must be available for such advice to be considered by the consulting party. Sufficient, in that context, does not mean ample, but at least long enough to enable the relevant purpose to be fulfilled. By helpful advice, in this context, I mean sufficiently informed and considered information or advice about aspects of the form or substance of the proposals, or their implications for the consulted party, being aspects material to the implementation of the proposal as to which the Secretary of State might not be fully informed or advised and as to which the party consulted might have relevant information or advice to offer. ${ }^{95}$

Although dealing with a statutory duty to consult in the United Kingdom, and not with the Crown's duty to consult Aboriginal people, the above excerpt is, nevertheless, a useful summary of the key components of judicially acceptable statutory consultation:

(a) a genuine invitation to give advice;

(b) a genuine consideration of that advice; and

92. Supra note 32 at para. 110 [emphasis added].

`3 [2001] 1 C.N.L.R. 361 (B.C.S.C.). See also Union of Nova Scotia Indians v. Canada, [1997] 4 C.N.L.R. 280 at $294-303$ (F.C.T.D.).

$94 \quad$ [1986] 1 All E.R. 164 (Q.B.) [Secretary of State for Social Services]. See also Fletcher v. Minister of Town \& Country Planning, [1997] 2 All E.R. 496 at 500.

"S Secretary of State for Social Services, ibid. at 167 [emphasis added]. 
(c) the provision of sufficient information and time to the Aboriginal party being consulted.

Based on the case law to date and the preceding discussion, the Crown's duty to consult Aboriginal people also appears to require the following:

(a) no unreasonable timelines be imposed, considering the relevant circumstances;

(b) government positions or decisions are properly explained;

(c) the Aboriginal concern is genuinely considered and addressed;

(d) Aboriginal people are dealt with reasonably and their rights taken seriously;

(e) there is no "sharp dealing"; and

(f) bona fide attempts are made to accommodate the interests of Aboriginal people made in the face of interference with Aboriginal and treaty rights.

\section{H. Ministerial Discretionary AUTHORITY}

Many instances of consultation between the Crown and Aboriginal people involve the use of ministerial discretionary authority. In $R$. v. Adams ${ }^{96}$ and Marshall II ${ }^{97}$ the Supreme Court of Canada clearly stated that where a Minister of the Crown exercises discretionary authority that may have an impact upon Aboriginal or treaty rights, then any such legislation setting out such ministerial discretionary authority must provide for consideration of potential interference with Aboriginal and treaty rights. Yet, notwithstanding this clear direction from the Supreme Court of Canada, no substantive amendments with respect to ministerial discretionary authority have been made to any federal, provincial or legislation consistent with the direction provided in Adams and Marshall.

The issue of the exercise of ministerial discretionary authority under the Nunavut Land Claims Agreement (NLCA) ${ }^{98}$ was considered in Nunavut Tunngavik Inc. v. Canada (Minister of Fisheries and Oceans). ${ }^{99}$ In this case, the issue concerned the Minister of Fisheries and Oceans' decision regarding turbot quotas affecting an area within the NLCA. Nunavut Tunngavik Inc. (NTI) argued that the Minister failed to consider the advice of the Nunavut Wildlife Management Board (NWMB), constituted under the NLCA. Justice Campbell held on review that the reference to consultation in the NLCA must be "meaningful inclusion of the NWMB in the Governmental decision-making process before any decisions are made." 100 The concept of "meaningful inclusion" is, on its face, a component of consultation and, in this case, within the terms of a treaty. Justice Campbell held that the Minister cannot simply receive and examine the advice and recommendations given by the NWMB. He concluded that the relationship between the Minister and the NWMB was intended to be "mandatory, close, cooperative and highly respectful." ${ }^{101}$ The message from the Court is that government

\% [1996] 3 S.C.R. 101 [Adams].

"7) Marshall II, supra note 59 at para. 33.

9* The Agreement between the Inuit of the Nunavut Settlement Area and Her Majesty the Queen in Right of Canada, ratified, given effect, and declared valid pursuant to s. 4(1) of the Nunavut Land Claims Agreement Act, S.C. 1993, c. 29.

[1997] 4 C.N.L.R. 193 (F.C.T.D.) [Nunavut Tunngavik l].

Ibid. at 211 .

IIII Ibid. at 210. 
must take a proactive stance when "considering" Aboriginal interests and advice when decisions and actions may adversely affect Aboriginal people.

The Federal Court of Appeal, while agreeing with the trial court's conclusion to set aside the Minister's decision, referred the matter back to the Minister for reconsideration. The Court of Appeal focused on whether the Minister gave special consideration to the adjacency and economic dependence principles required by the NLCA or misconstrued these principles in their application. The Court also rejected a number of the trial judge's conclusions regarding the interpretation given to the relevant provisions of the NLCA. The Court stressed that it will not "second guess" the Minister. ${ }^{102}$ The Court balanced this by noting that "the Minister's discretion in S. 7 of the Fisheries $A c t^{103}$ is no longer absolute when the exercise of that discretion affects the wildlife and the marine areas of the [Nunavut Settlement Area] and the wildlife management." 104

NTI again challenged the authority of the Minister of Fisheries and Oceans in the decision of Nunavut Tunngavik Inc. v. Canada (A.G.). ${ }^{105}$ In that decision, Blais J. dismissed a similar application (to the one in Nunavut Tunngavik 1) by NTI, which argued that the Minister erred in failing to apply the principles set out in the NLCA. In dismissing the application, Blais J. noted that:

the authority of the NWMB was in the nature of advice and recommendations and the minister did look into it. It was within the Minister's discretion and within the limits of the Agreement to take into consideration a number of factors including growth and decline in stock... Finally, in view of the situation that prevails in the Atlantic affecting every eastern province and territory with respect to Atlantic fishery, the end result provided by the Minister's decision on quota allocation can not be seen as unfair in view of the important decline in stock. $^{106}$

The difference in Nunavut Tunngavik 2 is the clear evidence that the Minister took into account all of the relevant considerations and made it clear that such consideration occurred. Additionally, there was a paper trail of the Minister's receipt and consideration of the applicable advice. The Federal Court of Appeal affirmed the trial court's decision:

because of the classically polycentric nature of the allocation of a fixed quota among competing groups of fishers, the proper standard of review of the exercise of the Minister's discretion is patent unreasonableness. The Minister's decision easily withstands that test. The decision has a rational basis, because it was open to the Minister to determine the quota by reference to quotas historically allocated for turbot fishing in Davis Strait, rather than to the allocation of quotas in other zones in the Atlantic fishery. ${ }^{107}$

The Nunavut Tunngavik decisions clearly demonstrate, with a particular focus on the proper exercise of ministerial discretionary authority, how a lack of proper consultation with 
NTI had an impact on the Minister's authority. The Nunavut Tunngavik decisions also demonstrate how a lack of administrative due process by government can be fixed to meet the standard required by, and owed to, Aboriginal people. In the second set of decisions, the Minister's decision regarding turbot quotas was able to withstand judicial scrutiny under s. 35(1). Moreover the Crown was found to have honoured its fiduciary relationship with Aboriginal people by ensuring that the basic administrative law and procedural fairness processes were put in place and fully implemented.

\section{CONSUltation AND INDUSTRY}

To date, the case law from the Supreme Court of Canada strongly suggests that any constitutional duty to consult rests solely with the Crown and not with private interests, such as oil or gas companies, other industries, or municipal governments. ${ }^{108}$ In the end, it rests with both the federal and provincial Crowns to be diligent in ensuring that their decisions, activities and legislation adequately account for and consider Aboriginal interests that may be so affected. This consideration and accounting must be done in good faith and transparently. Industry and third-party consultation with Aboriginal people has been based on governmental delegation (as in environmental review processes) or by way of voluntary actions by industry (as in mutually profitable joint development agreements).

Although the case law to date affirms that the duty to consult rests solely with the Crown, the Court of Appeal has taken a different view. In Haida, Lambert J.A. stated that Weyerhaeuser had an "obligation to consult the Haida," 109 that this duty was "enforceable, legal and equitable," 110 and that such duty to consult includes a duty of "reasonable accommodation." 111

Justice Lambert did not describe the source of Weyerhaeuser's duty to consult the Haida Nation. Presumably, the source was statutorily provided for in the Forest $A c t^{12}$ and the discretionary authority of the Minister and his offices, and is not derived from any fiduciary duty or special trust-like relationship that Weyerhaeuser may have to the Haida Nation. If the courts have found that a private third party, such as a logging company like Weyerhaeuser, owes a duty to consult Aboriginal people beyond any delegated statutory duties or obligations, and based on some constitutional or fiduciary obligations, they have done so without any supporting reasons.

101) Haida, supra note 3 at para. 48.

110 Ibid. at para. 52.

III Ibid. at para. 51. The use of the term "reasonable accommodation" results in an additional burden on the duty to consult, but is consistent with the Supreme Court of Canada decisions such as Sparrow, supra note 1, where the Supreme Court stated that when justified infringements are made on Aboriginal and treaty rights, the Crown should ensure that there is no undue hardship on the Aboriginal people, that their rights are infringed as little as possible and that the regulation at issue does not deny the holders of the right their preferred means of exercising the right. "Reasonable accommodation" is also sometimes used within the context of employee-employer relations and relies upon a case-by-case application, depending upon the circumstances.

112

R.S.B.C. 1996 , c. 157. 
In many important resource development situations, the Crown has informally delegated substantive execution of its duty to consult with Aboriginal people to the industry concerned with the development. Such delegation is merely doing what is reasonable in order to effect an appropriate consultation. Both federal and provincial governments have, in many instances, left industry to negotiate critical relationships between industry and Aboriginal people in respect of access to natural resources with a minimum of guidance and certainty that the negotiated settlement is a solid, long-term foundation for substantial investment and stability.

Such delegation should not prevent industry from exceeding the minimum standard required and should enable industry to continue to enter into economic and social-benefit agreements with Aboriginal groups. That being said, however, the need for government to become engaged in a clear and meaningful way with these industry initiatives is essential to ensure that such negotiated agreements have the requisite legal certainty that only the Crown can provide. In order to achieve its objectives, industry needs to be in contact with government, reminding and guiding government of its key role and assisting it in doing what is appropriate in balancing industry and Aboriginal interests.

Many of the Supreme Court of Canada decisions since 1982 dealing with s. 35 - as well as the British Columbia Court of Appeal's decisions in Taku River ${ }^{113}$ and Haida ${ }^{114}$ - stress the need for governments to get their consultation houses in order so that industry and Aboriginal people can look to the land base, whether for development, cultural, or other purposes, with a sense of certainty and stability.

\section{CONCLUSION}

Most governments in Canada are either increasing the expenditure of resources and energy to establish better consultation regimes or are considering doing so regarding their decisions that could impact upon the rights of Aboriginal people. Across Canada, a huge effort is being undertaken by governments to produce more detailed consultation manuals and guidelines, as well as more committees and infrastructure to deal with this issue.

Based on the preceding examination of the law regarding the duty of the Crown to consult Aboriginal people, there appear to be three general areas of concern: (1) the identification of the appropriate trigger for the Crown to consult Aboriginal people; (2) the requisite institutional clarity, communication, and co-ordination required within governments to ensure effective consultation; and (3) the necessary degree of procedural fairness and substantive integrity.

A fundamental area of concern is the governments' lack of appropriate triggers to engage their respective consultation regimes. An examination of some of the existing governmental consultation schemes, policies and guidelines that are in place across Canada reveal, in many instances, that these guidelines seem adequate and appear, on their face, to meet the basic standard of procedural fairness. However, what is missing from these guidelines is the proper 
engagement or use of these guidelines in appropriate circumstances. For example, in Haida ${ }^{115}$ the issue was not whether the government of British Columbia's consultation duties were engaged, but that those guidelines were not triggered. To date, the courts have been clear that any government decision, act or legislation that may infringe upon existing Aboriginal and treaty rights should be subject to consultation with the potentially affected Aboriginal people. A review of the guidelines indicates that, in many instances, governments have attempted to limit the application of their consultation guidelines to particular instances and to limit the resources expended on consultation generally.

There is no doubt that the Crown's duty to consult Aboriginal people places a significant burden on the Crown when it attempts to make decisions, to act or to use legislation that can negatively impact upon the rights of Aboriginal people. However, s. 35(1) of the Constitution Act, 1982 and the Crown's relationship with Aboriginal people requires that such consultation occur. Governments must ensure that they implement the appropriate triggers for broad-based consultation with Aboriginal people so as to ensure that all governmental decisions, acts or legislation can withstand scrutiny under s. 35(1).

A critical component to a successful consultation scheme is not only ensuring that the proper trigger is put in place, but that the consultation guidelines or policies are applied consistently and with the same degree of expertise and professionalism. Many governments view consultation as a subcategory of their dealings with Aboriginal people. This is accurate to some extent. However, a more accurate and perhaps more helpful understanding of the duty to consult Aboriginal people is to place the duty to consult within a pan-governmental context. The duty to consult affects almost all aspects of federal, provincial and territorial governments, and as such should be accorded the degree of importance that is required, particularly since the lack of proper consultation can have a serious impact on a government's ability to govern in a stable and certain manner. This element of institutional clarity ensures that the proper resources are put in place to facilitate adequate consultation. It also ensures strong leadership and institutional memory to facilitate reasonable and consistent decision-making.

Institutional clarity also ensures that there are proper communication procedures and lines of authority within the governmental organization so as to allow effective and efficient decision-making regarding consultation with Aboriginal people. Particularly helpful is a team approach to understanding what is required for consultation, as opposed to one individual being designated as the "sign-off" on consultation with Aboriginal people. In many instances, and as the case law demonstrates, common sense or reasonableness go a long way to ensuring that Aboriginal people are treated fairly, that their rights are taken seriously, and that the Crown's duty to consult has been met.

In Taku River, ${ }^{116}$ while the government of British Columbia's consultation guidelines were triggered, they were not fully implemented. The consultation process was adequate, but was short-circuited at its conclusion because of a political decision. It did not appear that the consultation guidelines in Taku River were faulty; rather, their implementation was weak.

Taku River, supra note 3. 
It is challenging for large institutions, such as governments, to put into place organizational and operational mechanisms to ensure a common sense or reasonable approach. While manuals, policies and guidelines can provide some focus to this important exercise, reality dictates that not every scenario can be anticipated by such policies and guidelines. Therefore, another approach must be utilized to assist the written guidelines. This approach requires individuals and teams being given clear authority to use common-sense and to make reasonable decisions that will ensure that the Crown meets its duty to consult.

Governments would be wise to implement consultation guidelines to ensure these guidelines are engaged and are not dependent upon minimalist legal interpretations of the case law regarding consultation. Governments lose little by consulting broadly and thoroughly with Aboriginal people, but have much to lose when Aboriginal people are not properly consulted. With or without proven Aboriginal title or treaties, the Crown's duty to consult Aboriginal people remains.

Additionally, consultation is relatively inexpensive when compared to the costs of litigation. Litigation can also have larger costs, including those relating to the uncertainty created in the business community each time the Crown loses a consultation-related decision, thereby building on the culture of adversarial action inherent in serial litigation. In short, consultation is not only the legally correct action to take, but it is the wise action to take. ${ }^{117}$

A careful review of the case law dealing with the Crown's duty to consult Aboriginal people and the broader principles of administrative law relating to relations between Crown and citizen makes it clear that "consultation" in the Aboriginal context describes an objective process which varies with the circumstances. While not exactly the same as the concept of "fairness" in administrative law, the procedural aspect of the duty to consult Aboriginal people is clarified conceptually by the substantial body of Anglo-Canadian law that has developed around the concept of the Crown's duty of fairness to its subjects.

Just as the duty of fairness rests upon the Crown in dealing with its subjects, the duty to consult rests with the Crown in its dealing with Aboriginal and treaty rights and its Aboriginal subjects. The adequacy of the Crown's exercise of its duty to consult Aboriginal people is measured by the same yardstick of "reasonableness" and "fairness" that the courts use to judge the appropriateness of any interference with the rights of a subject under general administrative law and in equity.

The peculiar nature of Aboriginal and treaty rights has resulted in the development of a separate Aboriginal law doctrine of the Crown's duty to consult Aboriginal people. This duty to consult did not emerge fully formed. It has developed slowly through judicial reasoning since Sparrow ${ }^{118}$ concurrent with judicial acceptance of the duty of fairness in administrative law. The coincidence of the underlying principles and the described structures of both duties is not surprising. Equally, such coincidence makes the well-developed jurisprudence on the duty of fairness and proper substantive decision-making a helpful guide to what the courts will accept as an appropriate measure of the exercise of the duty to consult. 
There are at least two choices for governments when dealing with the issue of consultation with Aboriginal people:

(1) continue down the road of reacting to Aboriginal litigation from a legal-minimalist perspective and using an overly bureaucratic and structured process, only to wait until the next judicial decision to clarify further the direction governments should take, or

(2) develop a proactive government strategy to consultation with Aboriginal people that understands the need for material institutional change in the way Aboriginal consultation is done and managed. This strategy requires a common-sense and dynamic approach and explicitly rejects the reactive history seen to date by governments. A proactive strategy is not only the right thing for Aboriginal people, but for all Canadians and industry, based upon a systematic understanding of the judicially established principles for fair dealing between Crown, industry and Aboriginal people.

Governments that are serious about dealing with the rights of Aboriginal people and creating and fostering a business environment that promotes economic growth will know that the current path represented by option one is untenable. Option two, or variations on it, must be considered by governments.

We must alter the worn viewpoint of victory and defeat when dealing with Aboriginal issues, whether from the perspective of Aboriginal people, governments or industry. The use of a legal lexicon to discuss what needs to be done may not be the best means to define what must be done. However, the courts have slowly developed the law in relatively clear terms. Aboriginal people and their rights must be treated reasonably and fairly and must be taken seriously. The common thread throughout all of the litigation and judicial decisions is the central and exclusive role that the Crown plays in resolving the Aboriginal question for Canada. It is time to govern responsibly, and the Crown's duty to consult with Aboriginal people forms a key component to this objective.

An understanding of the Crown's duty to consult is critical to achieving a lasting harmony among Aboriginal people, industry and governments. This duty becomes more relevant and immediate when scarce natural resources are involved. The challenge of changing the way the Crown consults with Aboriginal people is particularly pressing on provincial governments. Until recently, the provinces have not focused much of their attention or resources on issues relating to Aboriginal people, since Indians and lands reserved for Indians come within the exclusive legislative authority of Parliament under s. 91(24) of the Constitution Act, 1867. ${ }^{119}$ This jurisdictional confusion between the federal and provincial governments and the lack of co-operation and harmonization between these two levels of government regarding matters relating to Aboriginal people only adds to an already confusing and unstable environment.

It is almost axiomatic in Canada today that resource industries generally do a good job of fostering working relationships with Aboriginal people who have or allege that they have 
rights in the resources subject to industry's interest. However, making those working relationships certain for the life of the project cannot be achieved only through the diplomacy of industry. Certainty involves engagement by the Crown in the process of relationshipbuilding and, to the extent that such relationships require infringement of Aboriginal or treaty rights, it will be necessary for the Crown at the right time and in the right way to exercise its duty to consult. 